\title{
Different regulatory pathways are involved in the proliferative inhibition of two types of leukemia cell lines induced by paclitaxel
}

\author{
RUI-LONG XIA ${ }^{*}$, YAN LU* , LI-NA ZHU, SHI-FU ZHANG, FU-KUN ZHAO and CAI-YUN FU \\ Laboratory of Proteomics and Molecular Enzymology, School of Life Sciences, \\ Zhejiang Sci-Tech Untiversity, Hangzhou, Zhejiang 10018, P.R. China
}

Received May 13, 2013; Accepted June 25, 2013

DOI: 10.3892/or.2013.2624

\begin{abstract}
Paclitaxel, one of the broadest-spectrum anticancer agents, is currently being used in the treatment of patients with solid tumors. In the present study, we compared the effect of paclitaxel on two types of leukemia cells. Our results showed that paclitaxel could inhibit the proliferation of MEL and K562 cells in a dose- and time-dependent manner. The mechanism of proliferative inhibition in K562 cells treated by paclitaxel was related to the cell cycle arrest in the $G_{2} / M$ phase, as well as the induction of apoptosis. By contrast, MEL cells treated by paclitaxel showed significant characteristics of necrosis, which indicated that the mode of cell death induced by paclitaxel in these two types of leukemia cells differed. Advances in research of the cell cycle, apoptosis and necrosis will extend our understanding of the mechanisms of paclitaxel-induced cell death, particularly in leukemia cells. Further elucidation of the mechanisms of necrosis in MEL cells may expedite the development of improved paclitaxel-based regimens for cancer therapy.
\end{abstract}

\section{Introduction}

Paclitaxel $\left(\operatorname{Taxol}^{\circledR}\right)$, a potent drug of natural origin isolated from the bark of the Pacific yew, is an important antitumor drug with significant activity against ovarian, lung and breast cancer (1-3). As a drug of cancer chemotherapy, paclitaxel has an unusual chemical structure that is a complex diterpene having a taxane ring with a four-membered oxetane ring and an ester side chain at position C-13 endowed with a unique mechanism of action: it inhibits microtubules from disassembly (4). For example, paclitaxel enhances the polymerization of tubulin to stable microtubules and also interacts directly with microtubules (4) and $\beta$-tubulin gene mutations

Correspondence to: Professor Cai-Yun Fu, Laboratory of Proteomics and Molecular Enzymology, School of Life Sciences, Zhejiang Sci-Tech University, Hangzhou, Zhejiang 310018, P.R. China E-mail: fucy03@126.com

*Contributed equally

Key words: paclitaxel, leukemia cells, apoptosis, necrosis are strong predictors of resistance response to the antitubulin drug paclitaxel (5-7).

Since the unique action of paclitaxel against microtubules was discovered in the 1970s (8), considerable work has been carried out to characterize the mechanisms by which paclitaxel disrupts the normal function of microtubules and arrests the cell cycle at the $\mathrm{G}_{2} / \mathrm{M}$ phase. Little attention has been paid to other possible cellular actions of this antineoplastic agent. In 1993, Bhalla et al (9) demonstrated for the first time that the exposure of human myeloid leukemia HL-60 and KG-1 cells to clinically achievable concentrations of paclitaxel produced internucleosomal DNA fragmentation of 200 base-pair multiples, and also showed the morphologic changes characteristic of cells undergoing programmed cell death (PCD) or apoptosis. In recent years, apoptotic cell death induced by paclitaxel has been characterized by several laboratories in epithelial ovarian cancer (10), human gastric carcinoma cell lines (11), prostate tumors (12), adrenocortical carcinoma cell line (13) and human glioma cells (14).

These results clearly indicate that paclitaxel, in addition to its classical effect on microtubules and the arrest of cell cycle, may also possess significant cell-killing activity by induction of apoptosis. In the clinic, paclitaxel has been widely used in several malignant solid tumors, such as ovarian cancer, breast cancer and lung cancer (15). However, a poor level of in vivo induction of apoptosis was achieved during a phase I clinical study with paclitaxel therapy in 26 leukemia patients (16). In addition, paclitaxel has a significantly weaker cytotoxic effect on CD34 positive AML cells than CD34 negative leukemia cell lines, such as HL-60 and U937 (16). Considering the fact that leukemia is a heterogeneous disease with different cell types and immune phenotypes, it is necessary to investigate the effect of paclitaxel on different types of leukemia cell lines.

\section{Materials and methods}

Cell culture. Two types of established leukemic cell lines (MEL and K562) used in the present study were preserved in our laboratory, and were generous gifts from the Chinese Academy of Medical Sciences and Peking Union Medical College. The cell lines K562 and MEL were cultured in DMEM medium (Gibco-BRL Life Technologies) supplemented with $10 \%$ heat-inactivated fetal bovine serum (Sijiqing Biotech, Beijing, China) at $37^{\circ} \mathrm{C}$ in a humidified atmosphere of $5 \% \mathrm{CO}_{2}$. 

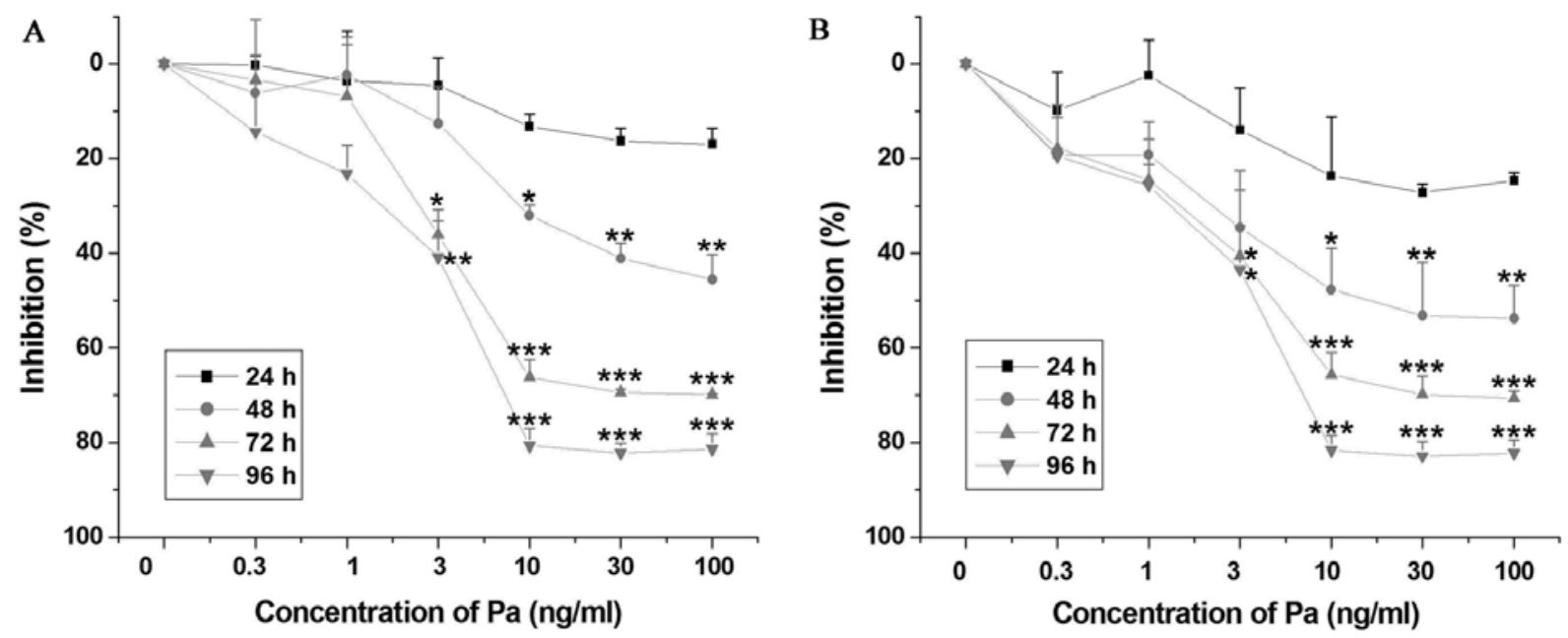

Figure 1. Effects of paclitaxel (Pa) on cellular growth of (A) MEL cells and (B) K562 cells using the MTT assay. The cellular growth was inhibited significantly in a dose- and time-dependent manner. The results are presented as the means \pm SEM of at least three independent experiments. ${ }^{*} \mathrm{P}<0.05,{ }^{* *} \mathrm{P}<0.01$ and ${ }_{* * *} \mathrm{P}<0.001$, statistically significant difference vs. the control.

Cell proliferation assay. MTT assay was used to determine the effect of proliferative inhibition on the two types of leukemia cell lines induced by incubation with paclitaxel (Huadong Medicine Co., Ltd., Hanzhou, China). Cells at the exponential growth phase were seeded at $3 \times 10^{3}$ cells/well in 96 -well microtiter plates in a volume of $180 \mu \mathrm{l}$ medium/well in the presence of various paclitaxel concentrations at a volume of $20 \mu \mathrm{l}$ or in the presence of isochoric PBS as the control. Then, $10 \mu \mathrm{l}$ of $5 \mathrm{mg} / \mathrm{ml}$ MTT (Sigma) was added to each well and incubated for $4 \mathrm{~h}$ at 24, 48, 72 and $96 \mathrm{~h}$, respectively. DMSO $(150 \mu 1)$ was added to dissolve the formazan crystals after centrifugation of the microtiter plates $(3,000 \mathrm{x} g$ for $15 \mathrm{~min})$ and the supernatant was gently removed. The absorbance was determined using microplate reader (Varioscan Flash; Thermo Scientific) at $570 \mathrm{~nm}$.

Inverted fluorescent microscope. MEL and K562 cells were incubated in the presence of paclitaxel or buffer alone for 24, 48, 72 and $96 \mathrm{~h}$. The final concentrations of paclitaxel for MEL and K562 cells were 100, 30, 10, 3, 1 and $0.3 \mathrm{ng} / \mathrm{ml}$; Hoechst $33342(10 \mu \mathrm{g} / \mathrm{ml}, 50 \mu \mathrm{l})$ was added and the suspension was further incubated for $5 \mathrm{~min}$ at room temperature in the dark. Microscopic analysis was carried out with an inverted fluorescent microscope (TE2000-U, Nikon, Tokyo, Japan).

Flow cytometric analysis of apoptosis and necrosis. Cells were first harvested at the exponential growth phase and mixed with paclitaxel at a concentration of $50 \mathrm{ng} / \mathrm{ml}$ for MEL cells, and $21 \mathrm{ng} / \mathrm{ml}$ for $\mathrm{K} 562$ cells, at $37^{\circ} \mathrm{C}$ in a humidified atmosphere of $5 \% \mathrm{CO}_{2}$ for $48 \mathrm{~h}$. For cell apoptosis and necrosis analysis, cells were resuspended at $2 \times 10^{6}$ cells $/ \mathrm{ml}$, and stained by Annexin V-FITC ( $5 \mu \mathrm{l}$ for $15 \mathrm{~min})$ and PI (10 $\mu \mathrm{l}$ for $5 \mathrm{~min})$ according to the instructions of the Cell Apoptosis kit (Kaiji Bio Co., Nanjing, China) and samples were analyzed with flow cytometry (FACSAria; BD Biosciences, Mountain View, CA, USA).

Flow cytometric analysis of cell cycle. Cells were first harvested at the exponential growth phase and mixed with paclitaxel at a concentration of $50 \mathrm{ng} / \mathrm{ml}$ for MEL cells and $21 \mathrm{ng} / \mathrm{ml}$ for $\mathrm{K} 562$ cells, at $37^{\circ} \mathrm{C}$ in a humidified atmosphere of $5 \% \mathrm{CO}_{2}$ for $24 \mathrm{~h}$. For cell cycle analysis, cells were resuspended at $2 \times 10^{6}$ cells $/ \mathrm{ml}$ and fixed in ice-cold $70 \%$ ethanol. According to the instructions of the Cell Cycle kit (Kaiji Bio Co.), each sample was resuspended in propidium iodide (PI) stain buffer (0.1\% Triton X-100, $10 \mu \mathrm{g} / \mathrm{ml}$ DNase-free RNase A, $50 \mu \mathrm{g} / \mathrm{ml}$ $\mathrm{PI}$ ) for $30 \mathrm{~min}$ and samples were analyzed with flow cytometry (FACSAria; BD Biosciences).

Statistical analysis. All results were confirmed by at least three independent experiments. The data are expressed as means \pm SEM. Comparisons of mean values were performed using the independent samples t-test in SPSS for Windows 11.5 software. A value of $\mathrm{P}<0.05$ was considered to indicate a statistically significant difference.

\section{Results}

Proliferation of leukemia cells is inhibited by paclitaxel. Using the MTT assay, our results showed that paclitaxel inhibited the proliferation of MEL and K562 cells in a dose- and time-dependent manner (Fig. 1). The $\mathrm{IC}_{50}$ values of paclitaxel in MEL and K562 cells at $48 \mathrm{~h}$ were 99.5 and $42.7 \mathrm{ng} / \mathrm{ml}$, respectively. Furthermore, morphological assessment of MEL cultures revealed that paclitaxel-induced marked cellular swelling should be called oncosis which leads to necrosis (Fig. 2), while a small part of the K562 cells incubated with paclitaxel showed marked cellular shrinking (Fig. 3).

Morphological observation using Hoechst 33342 stain assay. Hoechst 33342 is a non-toxic specific vital stain for DNA (17). Using Hoechst 33342 stain assay, our results showed that paclitaxel clearly induced necrosis in MEL cells (Fig. 4). However, there were evident apoptotic instead of necrotic cells in K562 cells treated by paclitaxel (Fig. 5).

Flow cytometry for the detection of apoptosis and necrosis. Cell apoptosis and necrosis were detected by flow cytometry 
A

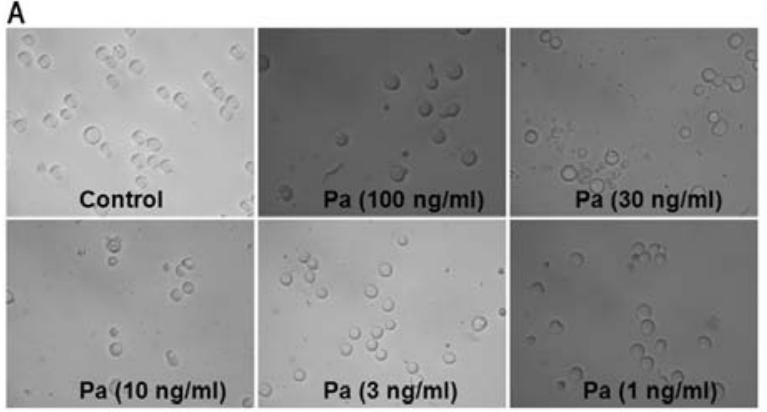

C

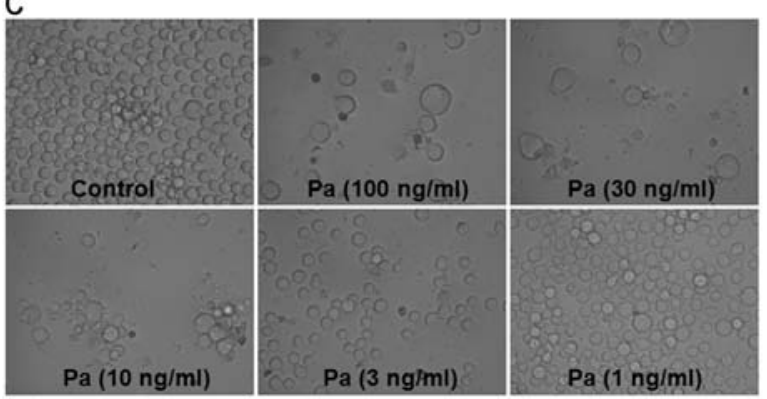

B

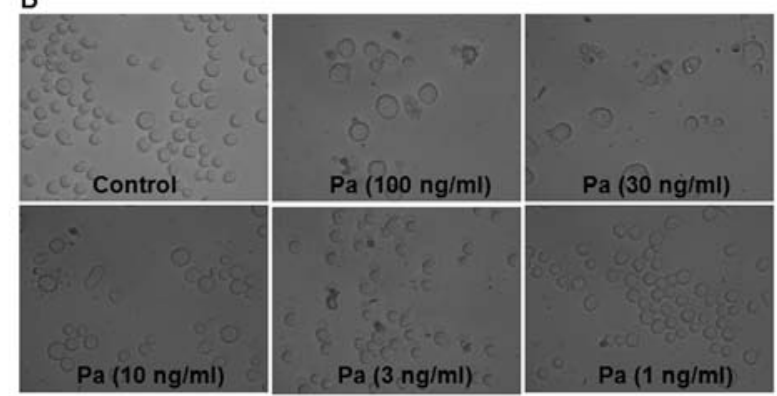

D

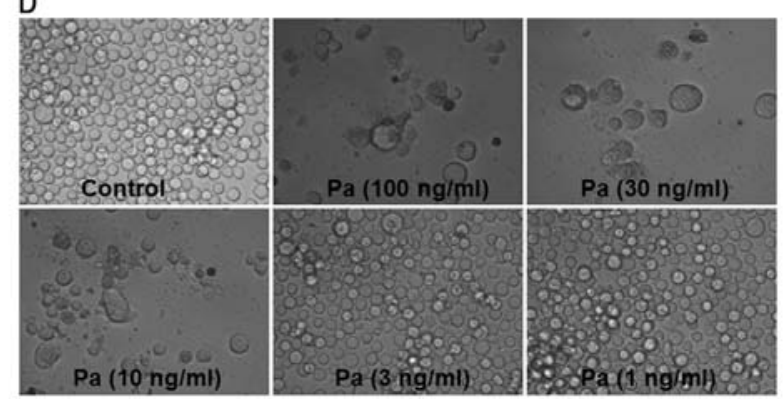

Figure 2. Morphological and quantity changes of MEL cells after paclitaxel (Pa) treatment at (A) 24, (B) 48, (C) 72 and (D) 96 h, respectively. Images were captured at x400 magnification. Representative images from three independent experiments are shown.

A

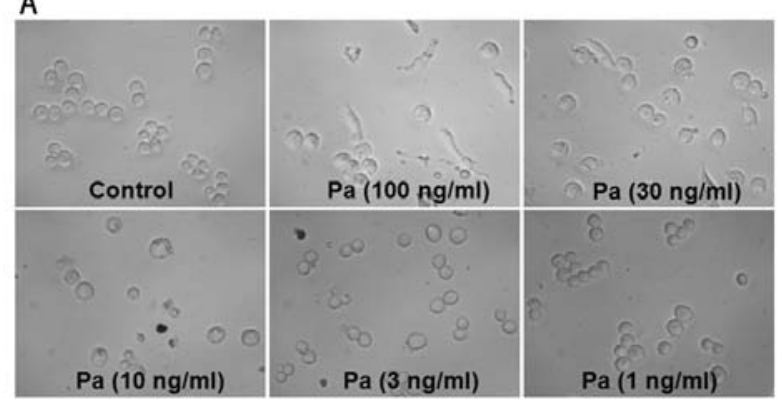

C

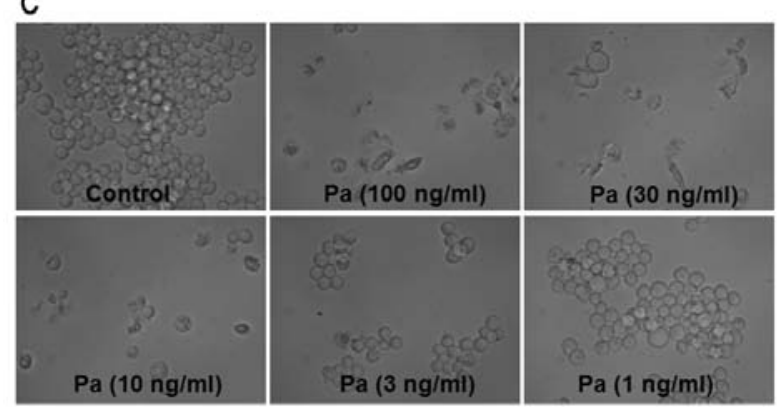

B

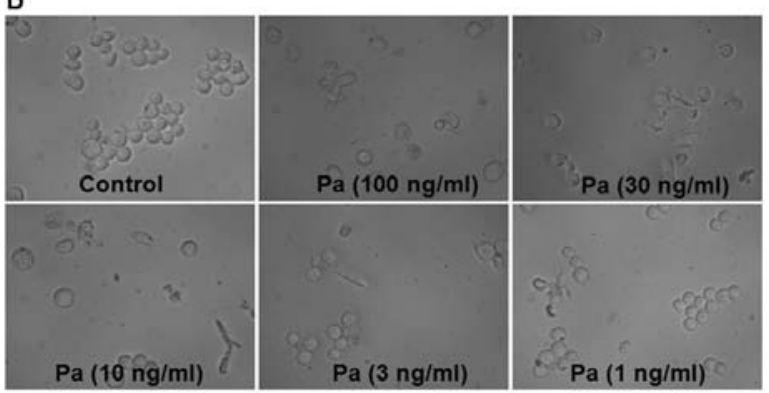

D

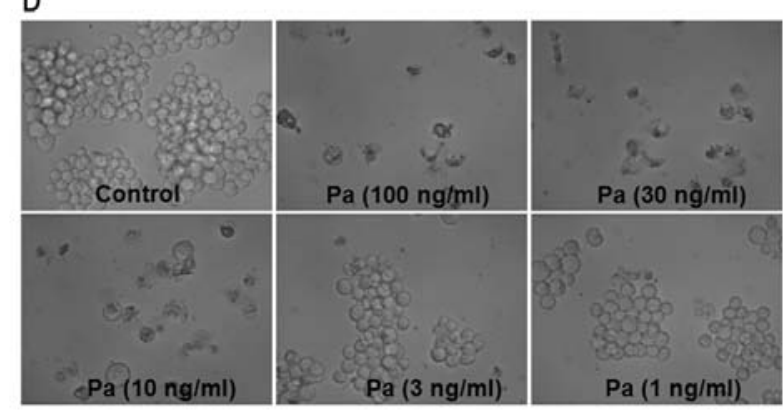

Figure 3. Morphological and quantity changes of K562 cells after paclitaxel (Pa) treatment at (A) 24, (B) 48, (C) 72 and (D) 96 h, respectively. Images were captured at $\times 400$ magnification. Representative images from three independent experiments are shown.

with Annexin V-FITC/PI dual staining. The amount of normal cells, early apoptosis, late apoptosis and necrosis was determined as the percentage of Annexin $\mathrm{V}^{-} / \mathrm{PI}^{-}\left(\mathrm{Q}^{-}\right)$, Annexin $\mathrm{V}^{+} / \mathrm{PI}^{-}(\mathrm{Q} 4)$, Annexin $\mathrm{V}^{+} / \mathrm{PI}^{+}(\mathrm{Q} 2)$ and Annexin $\mathrm{V}^{-} / \mathrm{PI}^{+}$ (Q1) cells, respectively (18). Our results showed that necrotic

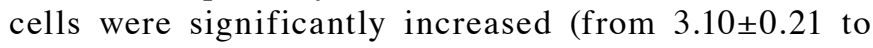
$14.68 \pm 1.76)$, while apoptotic cells were not significantly increased following paclitaxel treatment $(50 \mathrm{ng} / \mathrm{ml})$ in MEL cells for $48 \mathrm{~h}$, when compared to those in the control group that was treated with vehicle only (Fig. 6). However, in K562 cells, there was a marked increase of apoptotic cells from $5.87 \pm 0.77$ to $14.53 \pm 2.78$ following paclitaxel treatment $(21 \mathrm{ng} / \mathrm{ml})$ for $48 \mathrm{~h}$ compared with the control group, while there was no significant difference of necrotic cells between the paclitaxel treated group and the control group (from $2.16 \pm 0.53$ to $3.93 \pm 1.46$ ) (Fig. 7). These results are in accordance with the changes observed in cell morphology (Figs. 4 and 5). 


\section{A}

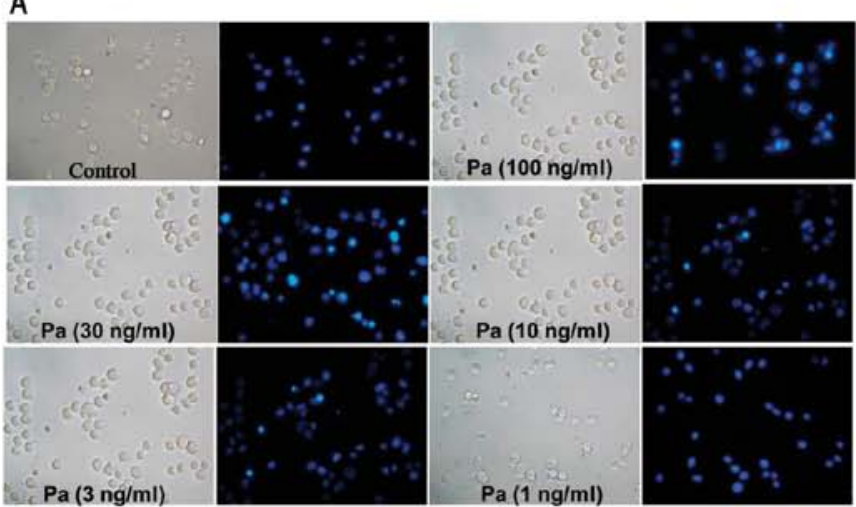

B

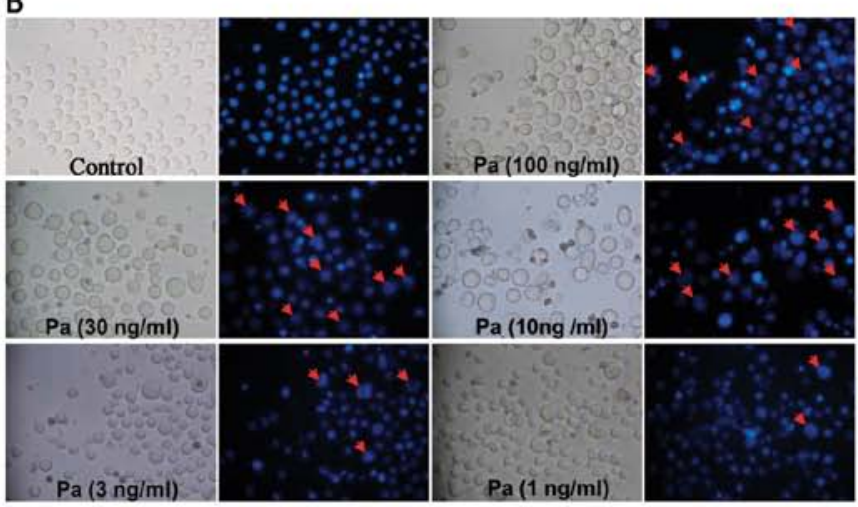

C

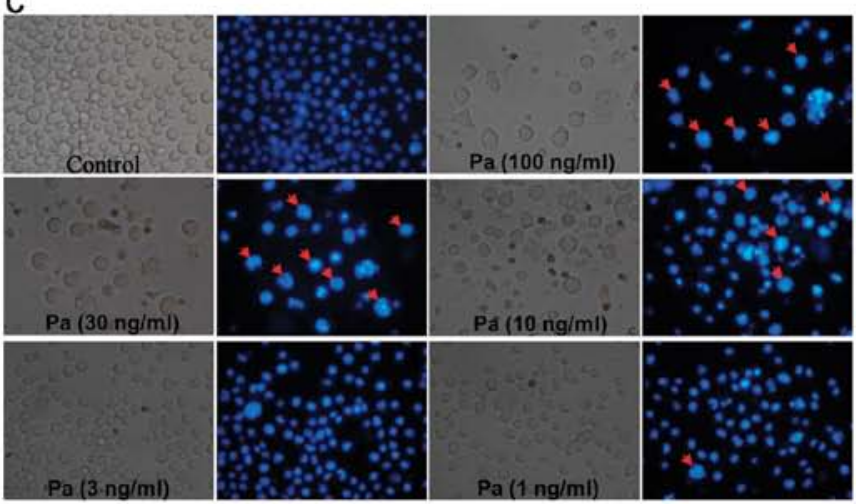

D

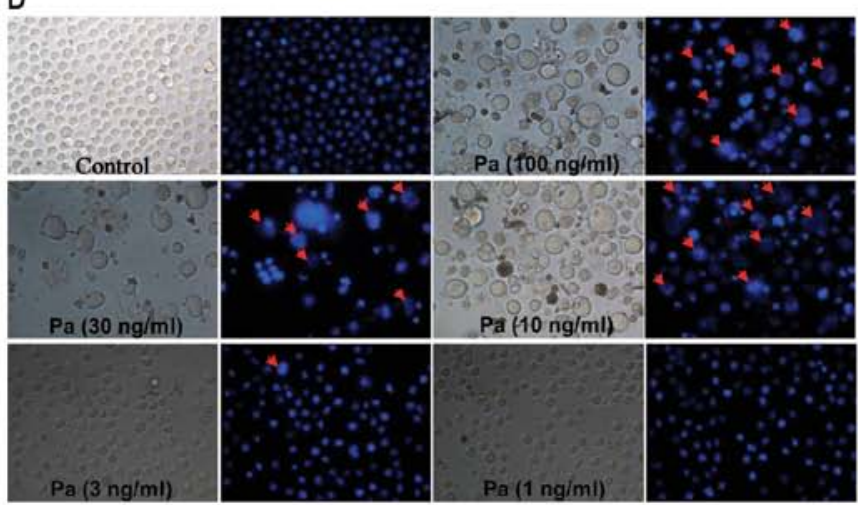

Figure 4. Effect of paclitaxel (Pa) on the nuclear morphological changes of MEL cells with the Hoechst 33342 uptake assay. MEL cells were incubated with buffer as the control or with Pa at each concentration for (A) 24, (B) 48 , (C) 72 and (D) $96 \mathrm{~h}$. The cells were then stained with Hoechst 33342 in the dark for $5 \mathrm{~min}$, and photographed by inverted fluorescent microscope (magnification, $\mathrm{x} 400$ ). A representative image from three independent experiments is shown. Red arrows indicate the representative necrotic cells.
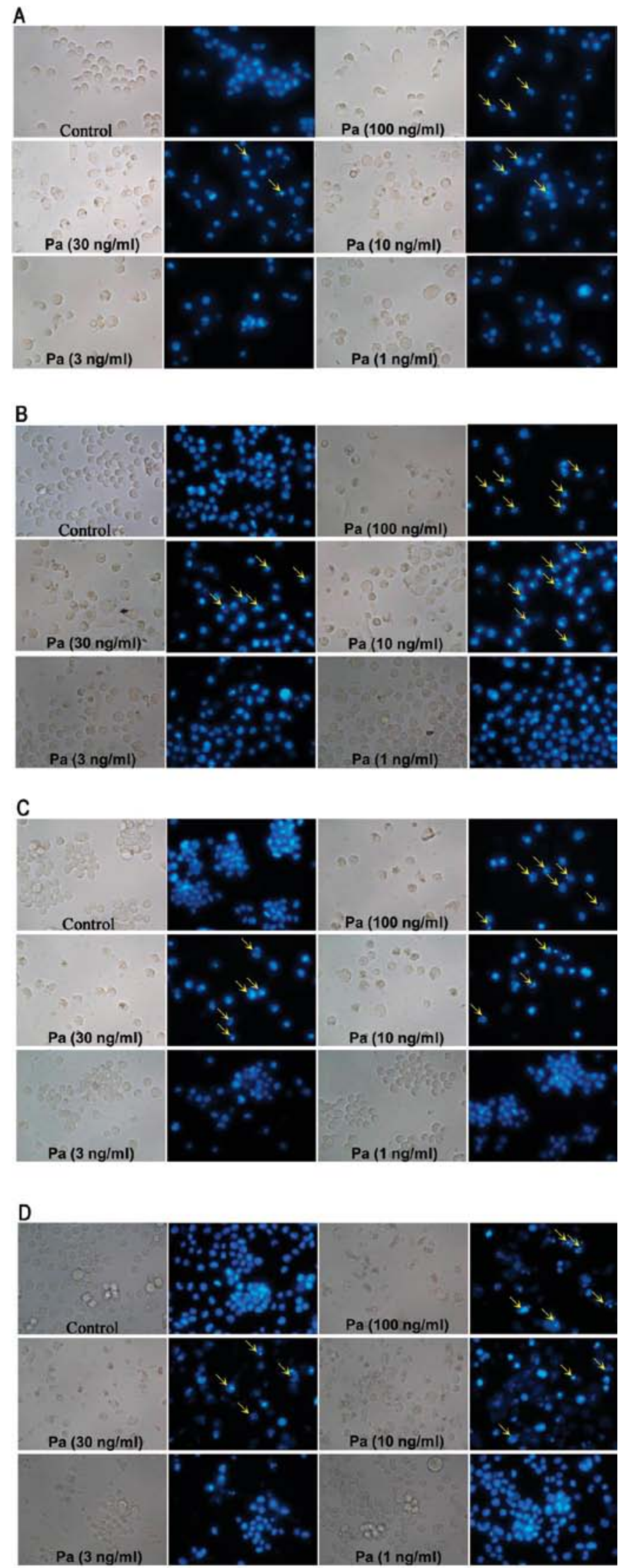

Figure 5. Effect of paclitaxel $(\mathrm{Pa})$ on the nuclear morphological changes of K562 cells with the Hoechst 33342 uptake assay. K562 cells were incubated with buffer as the control or with $\mathrm{Pa}$ at each concentration for (A) 24, (B) 48, (C) 72 and (D) $96 \mathrm{~h}$. Then cells were stained with Hoechst 33342 in the dark for $5 \mathrm{~min}$, and photographed by inverted fluorescent microscope (magnification, $\mathrm{x} 400$ ). A representative image from three independent experiments is shown. Yellow arrows indicate the representative apoptotic cells. 

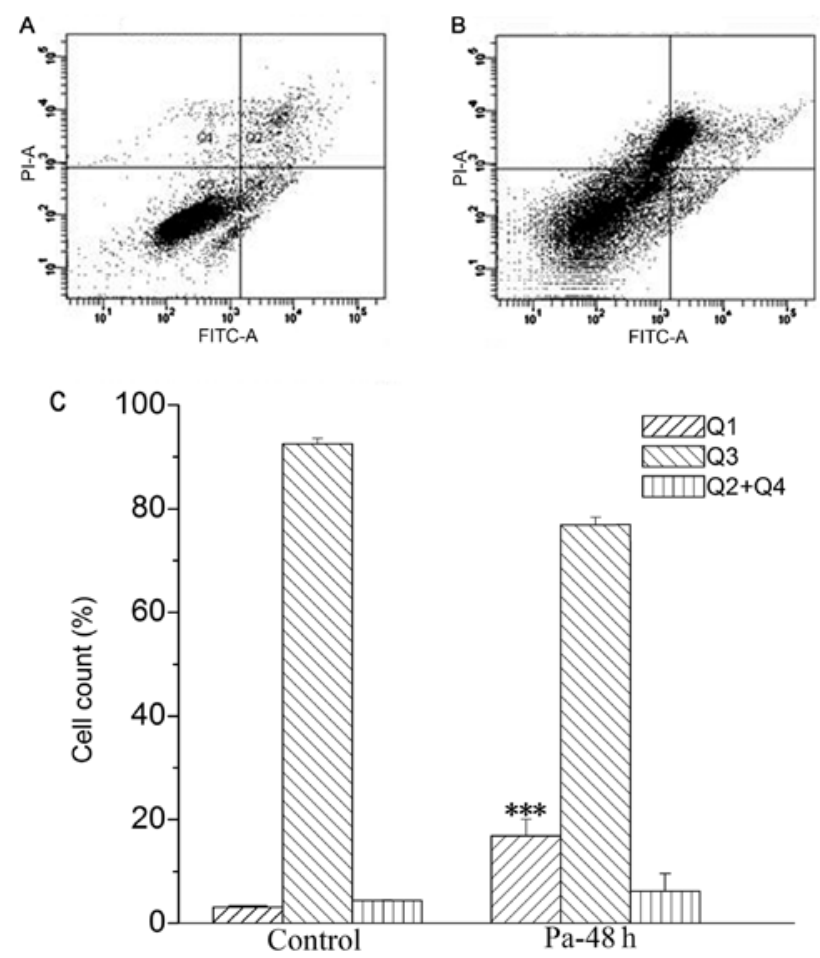

Figure 6. Effect of paclitaxel (Pa) on the apoptosis of MEL cells using flow cytometry. Apoptosis detection assays were carried out after incubation with $\mathrm{Pa}(50 \mathrm{ng} / \mathrm{ml})$ at $48 \mathrm{~h}$ (B) compared with control (A) by the double stain assay with Annexin V-FITC and PI. The results are presented as the means \pm SEM of at least three independent experiments $(\mathrm{C}) .{ }^{* * *} \mathrm{P}<0.001$, statistically significant difference vs. the control.

Paclitaxel induces significant $G_{2} / M$ phase arrest of the cell cycle in $\mathrm{K} 562$ cells. Flow cytometry analysis (PI stain) was used to determine the effect of paclitaxel on cell cycle distribution of K562 cells. As shown in Fig. 8, the percentage of K562 cells in the $\mathrm{G}_{2} / \mathrm{M}$ phase was increased significantly $(\mathrm{P}<0.01)$ from $14.66 \pm 0.50 \%$ (control group) to $85.96 \pm 3.24 \%$ after the treatment with paclitaxel at the concentration of $21 \mathrm{ng} / \mathrm{ml}$ for $24 \mathrm{~h}$, while the percentage of $\mathrm{G}_{0} / \mathrm{G}_{1}$ phase and $\mathrm{S}$ phase was decreased markedly, indicating that paclitaxel inhibited the proliferation of $\mathrm{K} 562$ cells by causing $\mathrm{G}_{2} / \mathrm{M}$ phase arrest of the cell cycle. However, it could not detect the normal cell cycle distribution in MEL cells treated by paclitaxel due to the necrosis (data not shown).

\section{Discussion}

Previous studies showed the efficacy of taxanes on human leukemic cell lines (16,19-21), as well as their effectiveness in inducing apoptosis in vivo (22) and in fresh leukemia cells in primary cultures (23). However, to the best of our knowledge, there is no report on the effect of paclitaxel on leukemia induced by virus. Friend virus is an acutely oncogenic retrovirus that causes erythroblastosis and polycythemia in mice $(24,25)$. In the present study, the MEL cell lines induced by friend virus were used to investigate the effect of paclitaxel on leukemia induced by virus, as well as to compare with that of human erythroleukemic cell line (K562 cells). Our present results showed the dose- and time-dependency of the antitumor effects of paclitaxel on these two types of leukemia
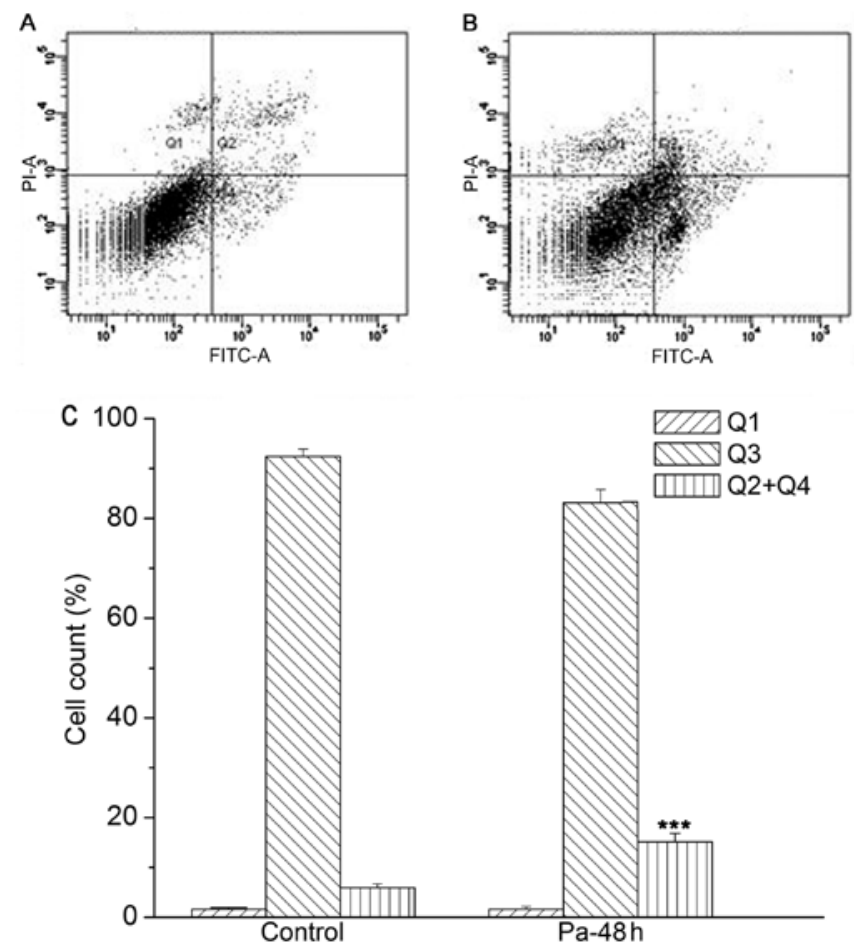

Figure 7. Effect of paclitaxel (Pa) on the apoptosis of K562 cells using flow cytometry. Apoptosis detection assays were carried out after incubation with $\mathrm{Pa}(21 \mathrm{ng} / \mathrm{ml})$ at $48 \mathrm{~h}$ (B) compared with control (A) by the double stain assay with Annexin V-FITC and PI. The results are presented as the means \pm SEM of at least three independent experiments $(C) .{ }^{* * *} \mathrm{P}<0.001$, statistically significant difference vs. the control.

cells, and the potency of paclitaxel in K562 cells was stronger than in MEL cells. Paclitaxel clearly induced apoptosis in $\mathrm{K} 562$ cells, which is in accordance with previous results (21). Also, there was a significant arrest of cell cycle to $G_{2} / M$ phase induced by paclitaxel in K562 cells, similar to the findings of a previous report (26). These findings suggest that paclitaxel induced K562 cell death involving the cell cycle and apoptosis (27).

By contrast, in MEL cells, paclitaxel could not induce significant apoptosis, which is different from that in K562 cells. Cell death is the process which culminates with cessation of biological activity. It is generally accepted that apoptosis and necrosis are two distinct, mutually exclusive, modes of cell death (28). One of the early events in apoptosis is cell dehydration. Loss of intracellular water leads to condensation of the cytoplasm followed by a change in cell shape and size: the originally round cells may become elongated and are generally smaller. Another change, perhaps the hallmark of apoptosis, is condensation of nuclear chromatin. In the present study, the phenomenon of apoptosis was evident in K562 cells treated by paclitaxel, while it was barely observed in MEL cells treated by paclitaxel. Necrosis is a passive, catabolic, and degenerative process with karyorrhexis and cell swelling prior to rupture of the plasma membrane, which is in contrast to apoptosis (29). Our present results showed that the MEL cells treated by paclitaxel exhibited significant characteristics of necrosis. Additionally, the normal cell cycle distribution in MEL cells treated by paclitaxel could not be detected due to the necrosis. It is therefore evident that the mode of cell death 

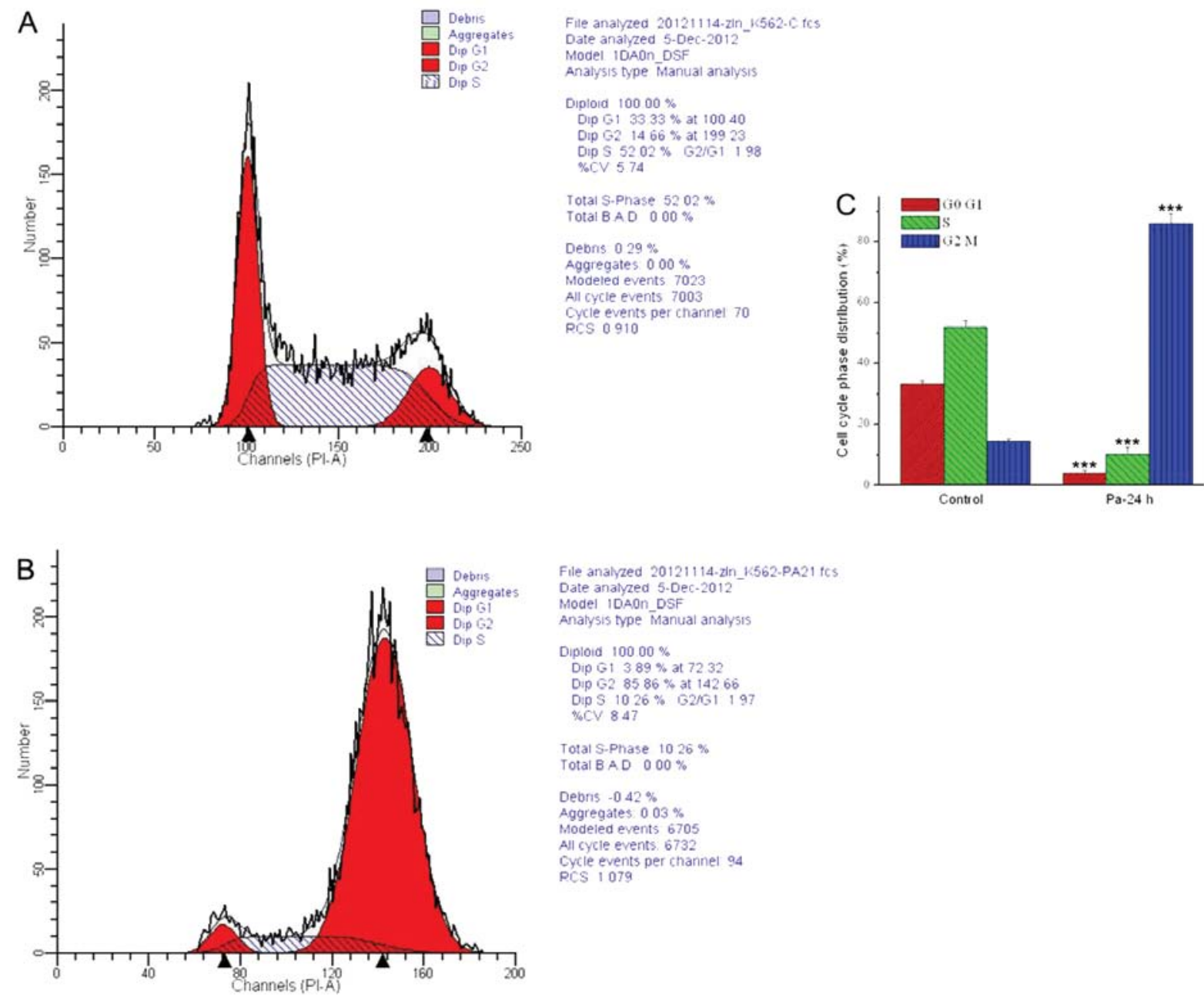

Figure 8. Effect of paclitaxel (Pa) on the cell cycle distribution of K562 cells using flow cytometry. Cell cycle detection assays were carried out after incubation with $\mathrm{Pa}(21 \mathrm{ng} / \mathrm{ml})$ at $24 \mathrm{~h}$ (B) compared with control (A) by PI-binding assay. The results are presented as the means \pm SEM of at least three independent experiments $(\mathrm{C}){ }^{* * * *} \mathrm{P}<0.001$, statistically significant difference vs. the control.

induced by paclitaxel in the two types of leukemia cells used in the present study is different.

In summary, paclitaxel is the prototype of a group of promising chemotherapeutic agents, taxanes, which specifically interact with microtubules. However, the present study showed that paclitaxel clearly induced necrosis in leukemia cells induced by virus, which is different from that of human erythroleukemic cells. Advances in the research of cell cycle, apoptosis and necrosis will extend our understanding of the mechanisms involved in paclitaxel-induced cell death, particularly in leukemia cells. Further elucidation of the necrotic mechanism in MEL cells may expedite the development of enhanced paclitaxel-based regimens for cancer therapy.

\section{Acknowledgements}

The present study was supported by a grant from the National Natural Science Foundation of China (no. 31000496), the 521 talent of Zhejiang Sci-Tech University and the Project supported by the Zhejiang Open Foundation of the Most Important Subjects (no. SWYX0903).

\section{References}

1. Burris HA III: Docetaxel (Taxotere) plus trastuzumab (Herceptin) in breast cancer. Semin Oncol 28: 38-44, 2001.

2. Belani $C$ and Lynch T: Docetaxel (Taxotere) in combination with platinums in patients with non-small cell lung cancer: trial data and implications for clinical management. Semin Oncol 28: 10-14, 2001.

3. Kaye S, Piccart M, Aapro M, Francis P and Kavanagh J: Phase II trials of docetaxel (taxotere ${ }^{\circledR}$ ) in advanced ovarian cancer - an updated overview. Eur J Cancer 33: 2167-2170, 1997.

4. Horwitz S: Taxol (paclitaxel): mechanisms of action. Ann Oncol 5: S3-S6, 1994

5. Monzó M, Rosell R, Sánchez JJ, Lee JS, O'Brate A, GonzálezLarriba JL, Alberola V, Lorenzo JC, Núñez L, Ro JY and Martín C: Paclitaxel resistance in non-small-cell lung cancer associated with beta-tubulin gene mutations. J Clin Oncol 17: 1786-1793, 1999.

6. Giannakakou P, Sackett DL, Kang YK, Zhan Z, Buters JT, Fojo T and Poruchynsky MS: Paclitaxel-resistant human ovarian cancer cells have mutant $\beta$-tubulins that exhibit impaired paclitaxeldriven polymerization. J Biol Chem 272: 17118-17125, 1997.

7. Ranganathan S, Benetatos C, Colarusso P, Dexter D and Hudes G: Altered beta-tubulin isotype expression in paclitaxel-resistant human prostate carcinoma cells. Br J Cancer 77: 562-566, 1998.

8. Wilson L, Bamburg J, Mizel S, Grisham L and Creswell K: Interaction of drugs with microtubule proteins. Fed Proc 33: 158-166, 1974. 
9. Bhalla K, Ibrado A, Tourkina E, Tang C, Mahoney M and Huang Y: Taxol induces internucleosomal DNA fragmentation associated with programmed cell death in human myeloid leukemia cells. Leukemia 7: 563-568, 1993.

10. Havrilesky LJ, Elbendary A, Hurteau JA, Whitaker RS, Rodriguez GC and Berchuck AW: Chemotherapy-induced apoptosis in epithelial ovarian cancers. Obstet Gynecol 85: 1007-1010, 1995

11. Chang YF, Li LL, Wu CW, Liu TY, Lui WY, P'eng FK and Chi CW: Paclitaxel-induced apoptosis in human gastric carcinoma cell lines. Cancer 77: 14-18, 1998.

12. Yen WC, Wientjes MG and Au JLS: Differential effect of taxol in rat primary and metastatic prostate tumors: site-dependent pharmacodynamics. Pharm Res 13: 1305-1312, 1996.

13. Fallo F, Pilon C, Barzon L, Pistorello M, Pagotto U, Altavilla G Boscaro M and Sonino N: Effects of taxol on the human NCI-H295 adrenocortical carcinoma cell line. Endocr Res 22: 709-715, 1996.

14. Terzis AJ, Thorsen F, Heese O, Visted T, Bjerkvig R, Dahl O, Arnold $\mathrm{H}$ and Gundersen G: Proliferation, migration and invasion of human glioma cells exposed to paclitaxel (Taxol) in vitro. Br J Cancer 75: 1744-1752, 1997.

15. Rowinsky EK: The development and clinical utility of the taxane class of antimicrotubule chemotherapy agents. Annu Rev Med 48: 353-374, 1997.

16. Al-Alami O, Sammons J, Martin J and Hassan H: Divergent effect of taxol on proliferation, apoptosis and nitric oxide production in MHH225 CD34 positive and U937 CD34 negative human leukaemia cells. Leuk Res 22: 939-945, 1998.

17. Richards W, Song MK, Krutzsch H, Evarts R, Marsden E and Thorgeirsson S: Measurement of cell proliferation in microculture using Hoechst 33342 for the rapid semiautomated microfluorimetric determination of chromatin DNA. Exp Cell Res 159: 235-246, 1985.

18. Shi Y, Wei Y, Qu S, Wang Y, Li Y and Li R: Arsenic induces apoptosis of human umbilical vein endothelial cells through mitochondrial pathways. Cardiovasc Toxicol 10: 153-160, 2010.
19. Gangemi RM, Tiso M, Marchetti C, Severi AB and Fabbi M: Taxol cytotoxicity on human leukemia cell lines is a function of their susceptibility to programmed cell death. Cancer Chemother Pharmacol 36: 385-392, 1995.

20. Haldar S, Basu A and Croce CM: Bcl2 is the guardian of microtubule integrity. Cancer Res 57: 229-233, 1997.

21. Gangemi RM, Santamaria B, Bargellesi A, Cosulich E and Fabbi M: Late apoptotic effects of taxanes on K562 erythroleukemia cells: apoptosis is delayed upstream of caspase-3 activation. Int J Cancer 85: 527-533, 2000.

22. Seiter K, Feldman EJ, Traganos F, Li X, Halicka HD, Darzynkiewicz Z, Lederman CA, Romero MB and Ahmed T: Evaluation of in vivo induction of apoptosis in patients with acute leukemia treated on a phase I study of paclitaxel. Leukemia 9: 1961-1966, 1995.

23. Consolini R, Pui C-H, Behm FG, Raimondi SC and Campana D: In vitro cytotoxicity of docetaxel in childhood acute leukemias. J Clin Oncol 16: 907-913, 1998.

24. Ney PA and D'Andrea AD: Friend erythroleukemia revisited. Blood 96: 3675-3680, 2000.

25. Friend C: Cell-free transmission in adult Swiss mice of a disease having the character of a leukemia. J Exp Med 105: 307-318, 1957.

26. Yusuf R, Duan Z, Lamendola D, Penson R and Seiden M: Paclitaxel resistance: molecular mechanisms and pharmacologic manipulation. Curr Cancer Drug Targets 3: 1-19, 2003.

27. Wang TH, Wang HS and Soong YK: Paclitaxel-induced cell death: where the cell cycle and apoptosis come together. Cancer 88: 2619-2628, 2000.

28. Darzynkiewicz Z, Juan G, Li X, Gorczyca W, Murakami T and Traganos F: Cytometry in cell necrobiology: analysis of apoptosis and accidental cell death (necrosis). Cytometry 27: 1-20, 1997.

29. Majno G and Joris I: Apoptosis, oncosis, and necrosis. An overview of cell death. Am J Pathol 146: 3-15, 1995. 